\title{
Interaction effects of Personality and Gender on Brain writing creativity and emotional Intelligence in Fostering Peacebuilding Skills among Nigerian adolescents
}

\author{
Azeez, Razaq Olugbenga \\ Educational Foundations and Counselling, Olabisi Onabanjo University Ago-Iwoye, Ogun State, \\ Nigeria
}

\begin{abstract}
This study sought to establish the moderating effects of personality and gender on brainwriting creativity and emotional intelligence in fostering peacebuilding among adolescents. A pre-test-post test $3 \times 2 \times 2$ factorial design was adopted. Two hundred and sixteen (216) participants were chosen among senior secondary students in three randomly selected public secondary schools participated in the study. Data were collected using Peacebuilding Scale and Ten-Item Personality Inventory. Analysis of variance was employed for data analysis with significant level fixed at 0.05 . Findings from the study revealed among others that the treatments significantly affect participants' peacebuilding; that personality did not interact with treatment to create significant effects; that personality and gender did not interact with treatment to create any significant effects on the criterion variable. The study suggested that EQ and creativity be integrated into the school curriculum as one of the teaching subjects in secondary schools and be part of the training modules for personnel in the workplace.
\end{abstract}

Key words: Personality, Brainwriting, Creativity, Emotional Intelligence, Peacebuilding Skills, Adolescents

Conflict, no doubt, is inevitable in human societies and it is in a continuum. It might results from multiple reasons; ranging from competition over resources, power differentials, feeling of inequality, faulty attributions to stereotypes (Donohue \& Kolt, 1992). Conflicts may be expressed in form of civil disturbance, riot, secession and war. It can be in form of a debate or contest, a disagreement, argument, dispute, quarrel, a struggle, battle or confrontation, or a state of unrest, turmoil or chaos. Fajana, (2002) however notes that certain amount of conflict in human environment is healthy; indicating that individuals and groups are vibrant. Thus, conflict may be a vehicle of change.

Conflict has caused lots of damage to humanity. The World Bank (2011) in its World Development Report estimates that 1.5 billion people live in 'conflict affected' countries. Conflict affects all strata of the society especially women and adolescents. Some adolescents are conscripted as child-soldiers; some as transporters of firearms while others are forced into prostitution. Cases abound on the effect of conflict to mankind. From Liberia to Sierra Leone; from Iraq to Afghanistan; from the Arab spring to Islamist insurgency in Mali, Sudan and Nigeria; from humanitarian crises in the middle-east to the refuge influx-outflux in Europe; from minor domestic crises to international large scale wars, the management approaches employed rather than the wars determine to a reasonable extent, lasting solutions to the issues. Jeong, Lerche and Susnjic (2008) noted that there are diverse ways of dealing with a broad range of conflicts. These include negotiation, adjudication, mediation, arbitration, problem solving workshops, and consensus building.

The ultimate outcome in any conflict resolution process would be to achieve peace. Achieving a positive outcome in conflict situations requires skills in peacebuilding. Peacebuilding articulates a sprawl of activities, from government and international interventions to highly localised and informal practices. Political negotiations to end a war, the deployment of peacekeepers to maintain a ceasefire, truth telling commissions and memorials, arts and cultural practices that reach across sectarian boundaries - all qualify for inclusion in peacebuilding. Peacebuilding mechanisms generate interactions between conflicting parties and build an environment of understanding and trust. 
Boutros-Ghali (1992) described peacebuilding as a set of actions undertaken to prevent the recurrence of conflict that may take the form of concrete cooperative projects that link two or more countries in a mutually beneficial undertaking, which not only can contribute to economic and social development, but can also enhance the confidence fundamental for peace. Peacebuilding therefore aims to reduce the need for conflict by addressing the problems and damage within a community.

Peacebuilding became part of the policy vocabulary through the United Nations Agenda for Peace: Preventive Diplomacy, Peace Making and Peacekeeping of 1992, and has evolved considerably among practitioners, policy makers and the general public over the past decade. The mid-1990s witnessed a rapid increase in peacebuilding activities by a variety of actors, ranging from international and regional organisations (the United Nations, the European Union, the African Union) to academic institutions, foundations, civil society groups, social movements, business groups, and the media.

Peacebuilding is imbued with an important proactive intuition. It speaks to what is possible in the creation and re-creation of human societies, and imagines new actions and ways of doing rejuvenated lives and patterns of living. Thus, while peacebuilding may emerge in reaction to a situation of conflict, it seeks to be proactive in laying the foundations - through re-birthing - to also prevent conflict in the future. In this, one can see the potential relevance of peacebuilding for all societies and all times. Truly, peacebuilding can be thought of as an essential life skill. In schools and workplaces, homes and communities, peacebuilding can play a role in transforming the present and moving towards a future with greatly reduced incidences of conflict (Fisher, et al. 2000). This is true whether or not a society is emerging from war. Peacebuilding is a transformational process looking into the both the root cause of conflict and undertake designed programme to promote longterm stability and justice

Achieving peace in all spheres of human lives requires some level of creativity and emotional competencies. Thus, this study proposed the inclusion of these variables in peace and regular education to foster harmonious relationship among community members. Creative thinking requires reaching a new, original synthesis by establishing links between seemingly unrelated concepts. In this process, analogical thinking, which is defined as establishing links between what is already known (source or analog) and new information (target), plays an active role (Kadayıfçı, 2008). Creativity is present at birth, but develops only in a suitable context and environment. Providing this appropriate context and environment to children at an early age is only possible if there are educational processes that are supportive of creativity (Yıldırım, 2014). Creativity is related to the ability of an individual to express themselves (Hanley and Abell, 2002), and Sasser (2006) thinks of creativity, innovation and integration as parts of the same whole.

Various creativity techniques abound. This study employs the brainwriting creativity technique. Brainwriting is an idea-generating method that involves everyone in a group activity. Brainwriting enables a group to generate ideas and solutions to several problems/issues simultaneously on paper. The group involvement is focused and individualistic, yet it taps into collective input as participants build on each other's ideas. Brainwriting is a group creativity technique which requires the participative members to silently build on each others' ideas. It is a way of collecting ideas from less vocal team members through silent written generation of ideas and eliminates the verbal sharing of ideas (Akinboye, 2003; VanGundy, 1999).

The brainwriting technique starts in a similar way to brainstorming, that is, a problem is defined and a group assembles to come up with solutions, first in large quantities and second in a qualitative listing. The key difference is that, in brainwriting, each participant thinks and records their ideas individually and anonymously and without any verbal interaction. These relatively small differences change the quantity of ideas and the dynamics of the group. While brainstorming encourages a group to generate creative ideas verbally where, without censorship, only the most vocal people tend to participate, brainwriting is a method of simulating new ideas by writing them and it is believed to be advancement over and above brainstorming.

Brainwriting encourages a more uniform participation within a group. Brainwriting, a variation of brainstorming, combines free associating with individual work and allows better concentration. Studies (Michinov, 2012; Orija, 2015) have shown that brainwriting can be used to reengineer the skills of workers in an organisation, enhance creative performance and engender 
creativity among civil servants. de Bono (2000) reports that some people are much better at generating ideas by writing.

While early literature had laid more emphasis on intelligence quotient in measuring human successes in school and workplace, recent research findings have proved that having a high cognitive intelligence is not enough to ensure success in ones endeavour. In fact, it has been established that "Intelligent Quotient (IQ) accounts for only 20 percent of the factors that determine success in life" (Chemiss, Goldman, Emmerling, Cowan, \&Adler 1998, p. 26).Introducing emotional intelligence (EI/EQ) into human endeavours became imperative. In fact, emotional intelligence has become an increasingly popular topic within the fields of psychology and management (Grandey, 2000; Law, Wong, \& Song, 2004; Mayer, Roberts, \& Barsade, 2008).

Many of the most successful people in academic, business and social world have a high degree of what has become known as Emotional Intelligence (Azeez, 2015a; Azeez, 2015b; Berenson, Boyles \& Weaver, 2008; Deniz, Tras \& Aydogan, 2009). Emotional intelligence has recent time attracted a lot of significance in academic literature (Adeniga, Ayodele, Adeoye \& Oyerinde, 2015; Iro-Idoro, 2014; Mabekoje, 2012).

While discussing conflict the personality structure of the individual may be a valid concept. Human personality has been found to affect behaviour outcomes (Joshanloo \& Afshari, 2009; Lischetzke \& Eid, 2006; Lucas \& Baird, 2004; Strobel, Tumasjan, \& Sporrle, 2011; Zelenski, Santoro $\&$ Whelan, 2012).The personality of individual to some extent has significant role to play on his level of creativity and problem-solving (Orija, 2014). Usually, when we talk about personality, it is all about what makes individuals different from one another.

A McCrae and Costa's (1992) Big Five Model personality traits schemata is often used to assess personality in recent times. The model explains extraversion and introversion from five main components of (i) openness to experience, (ii) conscientiousness, (iii) extroversion, (iv) agreeableness and (v) neuroticism. Personality is seen as a behaviour which differentiates one person from another (Alharbi \& Wan Khairuzzaman, 2012; Beer \& Brooks, 2011) and provides acumen whether a person will do some specific job, in comparison to others (Sackett, Gruys \& Ellingson, 2002). Personality is the effective tool that predicts job performance (Ozer \& Benet-Martinez, 2006; Schulman, 2011).

Since there are differences in how boys and girls are socialised in our society, gender may facilitate the influence of training programmes on the peacebuilding skills of subjects. This can be sustained by research outcome of previous study on peacebuilding that indicated that conflict has its toll differently on different sexes (World Bank, 2011). The present study therefore considers personality gender as second level independent variables to determine its influence on peacebuilding of adolescents.

While acknowledging the fact that many researchers have conducted studies on the effectiveness of different creativity techniques and emotional intelligence at fostering performance and achievement; the effectiveness of brainwriting and emotional intelligence, put together, and moderated by personality and gender, in fostering peacebuilding has not been investigated; hence the need for the present study.

\section{HYPOTHESES}

1. There is no significant personality difference in the effects of emotional intelligence and brainwriting creativity training on participants' peace-building skills.

2. There is no significant interaction effect of gender and personality types on the effectiveness of emotional intelligence and creativity training on the peace-building skills of participants.

\section{METHOD}

\section{Design and Subjects}

A $3 \times 2 \times 2$ factorial design was employed. The various factors are treatments, which exist at three levels (emotional intelligence and Brainwriting groups and control group), personality which was observed at two levels (introversion and extraversion)and gender (male and female). A total of 216 senior secondary school adolescents randomly selected from 3 public secondary schools in Ogun East Senatorial District participated in the study. Seventy-two (72) of them each were randomly assigned to the two treatment groups and control group with regards to gender in each of the sample school. On the whole, a total of 108 males and 108 females participated in the study. 
Instrumentation: This study made use of two instruments for data collection. The first instrument was used to obtain information concerning the dependent variable (peacebuilding skills) and the second instrument for personality delineation.

Peace-building Scale - Peacebuilding was measured with a 23-item self-designed peacebuilding scale. The scale measured the three factors of: reconstruction, reconciliation and rehabilitation. Each of the twenty-three items was rated on a 4-point scale ranging from 1 (disagree strongly) to 4 (agree strongly). Estimation of the test-retest reliability for the Peacebuilding Scale, with four weeks interval, yielded an index of .76.

Ten-Item Personality Inventory (TIPI) - Personality was measured using the Ten-Item Personality Inventory (TIPI) developed as a very brief measure of personality by Gosling, Rentfrow and Swann (2003) to measure the Big Five factors of: extraversion, emotional stability (neuroticism), conscientiousness, agreeableness, and openness to experience. Each of the ten items was rated on a 7point scale ranging from 1 (disagree strongly) to 7 (agree strongly) with a header captioned I see myself as: Sample items are "extraverted, enthusiastic" for extraversion; "critical, quarrelsome" for agreeableness; "dependable, self-disciplined" for conscientiousness; "calm, emotionally stable" for emotional stability (neuroticism); and "conventional, uncreative" for openness to experiences. Cronbach alphas of $.68, .40, .50, .73$, and .45 for the extraversion, emotional stability (neuroticism), conscientiousness, agreeableness, and openness to experience scales respectively and estimation of the test-retest reliability for the TIPI with six weeks interval yielded an index of .72 have been reported (Gosling et al., 2003). Since its creation in 2003, many studies (e.g. Orija 2014; Mabekoje, 2012; Bunevicius, Katkute, \& Bunevicius, 2008; McElroy \& Dowd, 2007; von Hippel \& Gonsalkorale, 2005) have used the Ten-Item Personality Inventory and have reported evidence of reliability and validity. External correlations $(\mathrm{r}=.90)$ have also been established (Gosling et al. ., 2003). The TIPI exhibited identical convergent and discriminant validity as the full Big Five Inventory $(\mathrm{r}=.77)$. With similar reliability and validity measurements as the full inventory, the TIPI was chosen as a participant-friendly instrument that would limit tediousness (Gosling et al., 2003).

\section{Procedure}

Participants were welcomed and briefed on the purpose and the nature of the study, and were then randomly distributed into the 2 experimental groups and the control group with regard for gender. Peace Building Scale (PBS) and the TIPI were then administered on them at each level of the experimental group (i.e. emotional intelligence, brainwriting groups and control group) for the purpose of forming a baseline data against which to compute the post-treatment data. All participants in each experimental and the control group were thereafter given standardized instructions explaining the task involve in each treatment group through lectures, discussion, case study analysis, simulation exercise and take home assignments.

The tasks were presented at each level of the experimental group after each session of lectures/discussions. Participants were made to respond to them, first, as an individual and the whole group was also made to consider the same problem. To ensure that participants remain focused on the objective of the study (i.e. enhancing their peacbuilding level), they were encouraged to generate novel ideas/solutions to the problem presented before them. They were told to come up with novel ideas that were not typical response to the type of problem presented to them in normal day life situation.

The programme lasted for eight weeks of eight sessions of one hour of intensive training at each level of the experimental group. In each session, participants were given 30 minutes lectures/discussions. In some cases where participants could not provide solutions to the problem presented, they were encouraged to work on them at home. At the end of the 8th week of serious training, peacebuilding scale was re-administered on all participants to collect post-test scores.

The study was simultaneously carried out in three phases at the three locations. It should be noted that while the two experimental groups were subjected to the treatment packages, the control group received placebo treatment (Microsoft words processing) for the same duration as the treatment groups. 
Data Analysis: The Analysis of Covariance (ANCOVA) was used to analyze the main and interactive effects of the criterion variable, the independent variable and as well as the moderating variable. The null hypotheses were tested at 0.05 level of significance.

\section{RESULTS}

Table 1: $\quad$ Estimates of the interaction effect of treatment and personality on participants' peacebuilding skills

\begin{tabular}{|c|c|c|c|c|c|}
\hline \multirow{3}{*}{$\begin{array}{l}\text { Treatment Group } \\
\text { Control }\end{array}$} & \multirow{3}{*}{$\begin{array}{l}\text { Personality } \\
\text { Introversion }\end{array}$} & \multirow{3}{*}{$\begin{array}{l}\text { Mean } \\
66.398^{\mathrm{a}}\end{array}$} & \multirow{3}{*}{$\begin{array}{l}\text { Std. Error } \\
1.198\end{array}$} & \multicolumn{2}{|c|}{ 95\% Confidence Interval } \\
\hline & & & & Lower Bound & Upper Bound \\
\hline & & & & 64.036 & 68.760 \\
\hline \multirow{3}{*}{ Brainwriting } & Extraversion & $64.574^{\mathrm{a}}$ & 2.444 & 59.756 & 69.393 \\
\hline & Introversion & $71.172^{\mathrm{a}}$ & 1.620 & 67.978 & 74.367 \\
\hline & Extraversion & $71.054^{\mathrm{a}}$ & 1.316 & 68.460 & 73.649 \\
\hline \multirow[t]{2}{*}{ Emotional Intelligence } & Introversion & $66.972^{\mathrm{a}}$ & 1.697 & 63.627 & 70.318 \\
\hline & Extraversion & $69.801^{\mathrm{a}}$ & 1.300 & 67.238 & 72.364 \\
\hline
\end{tabular}

a. Covariates appearing in the model are evaluated at the following values: Pretest Peace Building $=66.3102$.

The results in Table 1 revealed that there was no significant two-way interaction effects of treatment and personality on adolescents' peacebuilding skills $\left(\mathrm{F}_{(2,203)}=1.011 ; \mathrm{p}>0.05\right)$. Therefore, the null hypothesis which stated that there is no significant difference in the effect of personality on the two treatments in enhancing adolescents' peacebuilding skills was accepted by this finding. The implication of the results is that personality would not interact significantly with treatment to affect the peacebuilding skills of participants.

This was revealed in the results in table above that participants with introversion personality in the brainwriting group had a mean score of 71.172 and a Standard Error of 1.620 compared with those in the emotional intelligence group who had a mean score of 66.972 and a Standard Error of 1.697; while those in the control group had a mean score of 66.398 and a Standard Error of 1.198. The finding further revealed that participants with extraversion personality in the brainwriting group had a mean score of 71.054 and a Standard Error of 1.316 compared with those in the emotional intelligence group had a mean score of 69.801 and a Standard Error of 1.1.300; while those in the control group had a mean score of 64.574 and a Standard Error of 2.444.

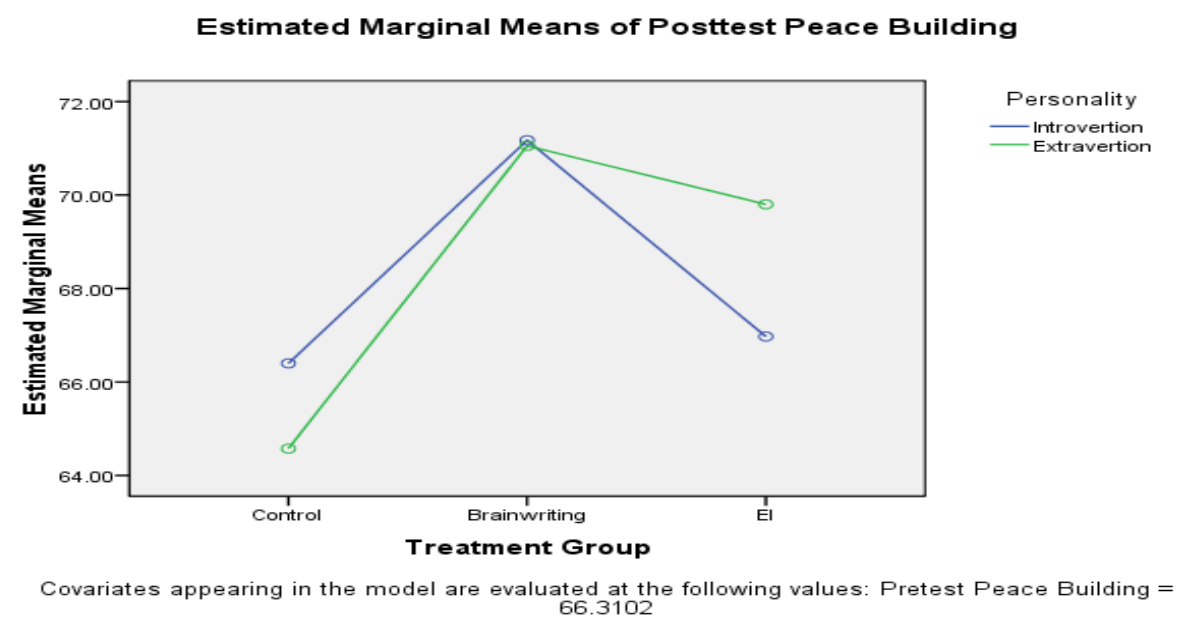

Figure 1: Interaction effect of treatment and personality on participants' peacebuilding skills

Figure 1 indicated that there was no significant interaction effect of treatment and personality on participants' peacebuilding skills. Though participants with introversion personality and extraversion personality in the brainwriting group had the highest peacebuilding skills mean scores 
(71.172) and (71.054) respectively, followed by their counterparts with introversion and extraversion personality in emotional intelligence group with mean scores of (66.972) and (69.801); while participants with introversion and extraversion personality in the control group had the lowest mean peacebuilding skills score (66.398) and (64.574), yet no significant effect was not found in the interaction of treatment and personality on peacebuilding behaviour of participants.

Table 2: Estimates of the interaction effect of treatment, personality and gender in enhancing participants' peacebuilding skill

\begin{tabular}{lllllll}
\hline & & & \multicolumn{4}{c}{ 95\% Confidence Interval } \\
\cline { 3 - 6 } Treatment Group & Gender & Personality & Mean & Std. Error Lower Bound & Upper Bound \\
Control & Male & Introversion & $64.796^{\mathrm{a}}$ & 1.526 & 61.787 & 67.806 \\
& & Extraversion & $61.804^{\mathrm{a}}$ & 4.305 & 53.316 & 70.291 \\
& Female & Introversion & $68.000^{\mathrm{a}}$ & 1.839 & 64.375 & 71.625 \\
Brainwriting & & Extraversion & $67.345^{\mathrm{a}}$ & 2.305 & 62.800 & 71.890 \\
& \multirow{2}{*}{ Male } & Introversion & $67.436^{\mathrm{a}}$ & 2.158 & 63.180 & 71.691 \\
& & Extraversion & $67.639^{\mathrm{a}}$ & 1.927 & 63.840 & 71.438 \\
& \multirow{2}{*}{ Female } & Introversion & $74.909^{\mathrm{a}}$ & 2.399 & 70.179 & 79.639 \\
Emotional & & Extraversion & $74.470^{\mathrm{a}}$ & 1.794 & 70.932 & 78.007 \\
& \multirow{2}{*}{ Male } & Introversion & $64.376^{\mathrm{a}}$ & 2.426 & 59.592 & 69.160 \\
& & Extraversion & $70.698^{\mathrm{a}}$ & 1.810 & 67.129 & 74.268 \\
& \multirow{2}{*}{ Female } & Introversion & $69.569^{\mathrm{a}}$ & 2.388 & 64.861 & 74.277 \\
& & Extraversion & $68.903^{\mathrm{a}}$ & 1.823 & 65.308 & 72.498 \\
\hline
\end{tabular}

a. Covariates appearing in the model are evaluated at the following values: Pretest Peace Building $=66.3102$.

The results in Table 2 revealed that there was no significant three-way interaction effect of treatment, personality and gender $\left(\mathrm{F}_{(2,203)}=1.055 ; \mathrm{p}>0.05\right)$ on adolescents' peacebuilding skills. The null hypothesis which stated that there is no significant interaction effect of treatment, personality and gender on adolescents' peacebuilding skills was by this finding accepted. The finding implies that adolescents' peacebuilding skills would not be affected by the interacting effect of treatment, personality and gender as indicated in the table above.

In the brainwriting group, male participants with participant with introversion personality had a mean score of 67.436 and a Standard Error of 2.158 compared with the female participants with introversion personality with mean score of 74.909 and a Standard Error of 2.399. Also, male participants with extraversion personality had a mean score of 67.639 and a Standard Error of 1.927 compared with their female counterparts with extraversion personality whose means score and standard errors were 74.470 and 1.794 respectively.

In the emotional intelligence group, male participants with participant with introversion personality had a mean score of 64.376 and a Standard Error of 2.426 compared with the female participants with introversion personality with mean score of 69.569 and a Standard Error of 2.388. Also, participants with male participants with extraversion personality had a mean score of 70.698 and a Standard Error of 1.810 compared with their female counterparts with extraversion personality whose means score and standard errors were 68.903 and 1.823 respectively.

In the control group, male participants with introversion personality had a mean score of 64.796 and a Standard Error of 1.526 compared with the female participants with introversion personality who had mean score of 68.000 and a Standard Error of 1.839. Also, male participants with extraversion personality had a mean score of 61.804 and a Standard Error of 4.305 compared with their female counterparts with extraversion personality who had means score of 67.345 and standard error of 2.305 . 


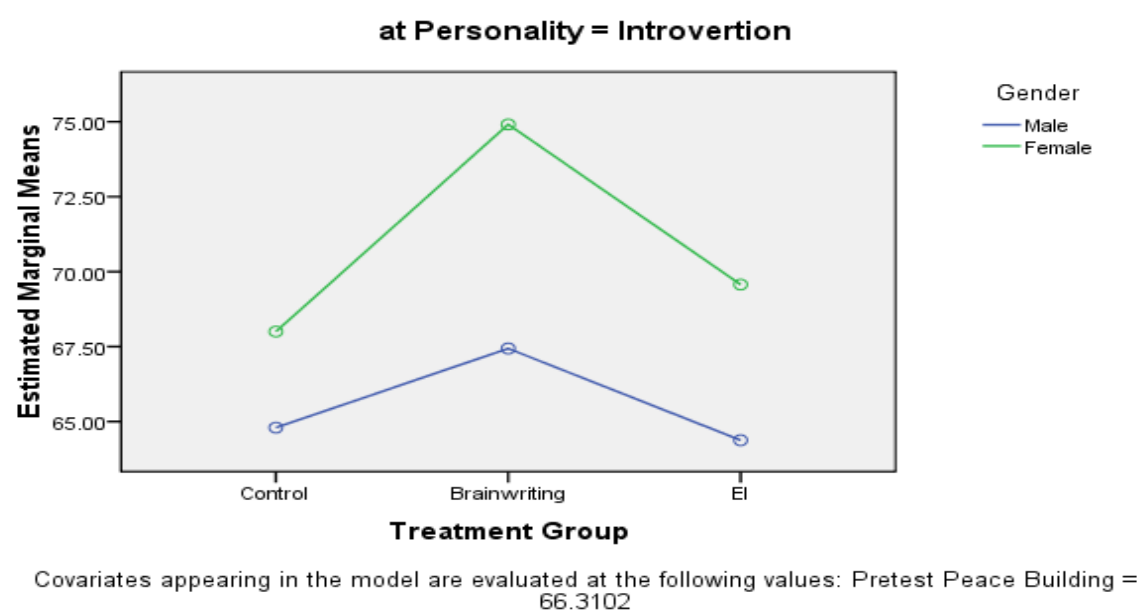

Figure 2: Interaction effects of treatment and personality on participants' peacebuilding skills with introversion personality.

The profile plots in Figure 2 show that though there is no significant difference between male and female with introverted personality, female participants have higher peacebuilding skills than their male counterparts. The peacebuilding skills of female are not just higher but are better than their male counterparts. This result shows female having higher peacebuilding skills competence based on their personality.

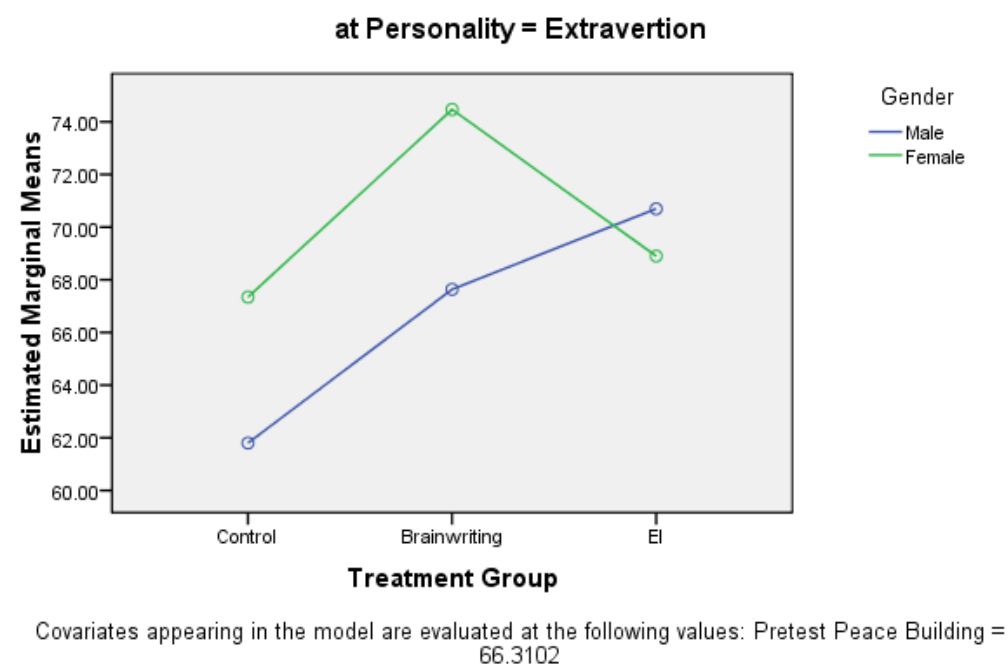

Figure 3: Interaction effects of treatment and personality on participants' peacebuilding skills with introversion personality.

The profile plots in Figure 3 show that though there is no significant difference between male and female with extraverted personality, female participants however, have higher peacebuilding skills than their male counterparts in the brainwriting and control groups but their male counterparts had higher mean score in the emotional intelligence group. This result shows female having higher peacebuilding skills competence based on extraversion personality except in emotional intelligence group. 


\section{DISCUSSION}

The first hypothesis sought the interactive effects of personality, emotional intelligence and brainwriting creativity training on participants' peace-building skills. The hypothesis was accepted based on the finding of the study. The result revealed that there was no significant two-way interaction effect of treatment and personality on adolescents' peacebuilding skills. This showed that personality would not interact significantly with the treatments to influence the peacebuilding skills of participants. This finding is in agreement with the finding of Orija (2015) that found no significant interactive effect of personality and treatments on participants. It however contradicted other studies such as (Joshanloo \& Afshari, 2009; Onabamiro \&Anatsui, 2015; Strobel, Tumasjan, \&Sporrle, 2011; Zelenski, Santoro \& Whelan, 2012) that found that personality affect behaviour outcomes.

Joseph, Jin, Newman \& O'Boyle, (2015) found mixed outcome as their meta-analysis results showed that EI measures strongly overlaps with a set of well-known psychological constructs (such as ability EI, self-efficacy, and self-rated performance, in addition to Conscientiousness, Emotional Stability, Extraversion, and general mental ability. Though personality did not show any significant influence on the criterion behaviour, however the mean score for extraverted participants was higher than those of the introverted participants. The implication of this is that extraverted personality is more likely to display more peacebuilding tendencies than their introverted individuals. This position is supported by earlier findings that showed that the extraverts are completely associated with emotional commitment (Erdheim, Wang \&Zickar, 2006); capable of practicing affirmative emotions (Costa \& McCrae, 1992); envisaged job gratification (Connolly \& Viswesvaran, 2000); emotionally firm and sure - that is why they possess contented personality (DeNeve \& Cooper, 1998); displayed contented life and job satisfaction (Judge et al. 2002) and are effective analyst of job performance for professions like administrations, social relation and sales (Barrick \& Mount, 1993).

The second hypothesis stated that there is no significant interaction effect of gender and personality types on the effectiveness of emotional intelligence and creativity training on the peacebuilding skills of participants. The results revealed that there was no significant three-way interaction effect of treatment, personality and gender on adolescents' peacebuilding skills. The null hypothesis seeking no significant interactive effect of treatment, personality and gender on adolescents' peacebuilding skills was, by this finding, accepted. The finding implies that adolescents' peacebuilding skills would not be affected by the interaction of treatment, personality and gender. This result agreed with the results of Adekola, (2012) and Ortese (2005) who found no interacting effects of treatment and moderators on participants' behaviour. The finding is also consistent with some previous work (Ayodele, 2014; Azeez, 2012; Baer \& Kaufman, 2005; Chan, 2005; McMaster, 2011; Ogunyemi, 2010) that found no gender influence on human accomplishments, including creativity, innovation, interpersonal skills and emotional labour.

The result, however, is at variance with the findings of previous researchers who found that individuals with high trait emotional intelligence and creativity skills are aware of their emotions and can regulate them in ways that can assist them in dealing with occupational stress, enhance performance, conflict management and promote their psychological well being (Adeyemo \& Ogunyemi, 2006; Bar-On, 2006; Ciarrochi, Deane \& Anderson, 2001; de Bono, 2008; Mikolajczak \& Luminet, 2008; Mikolajczak, Menil \& Luminet, 2007; Okunuga, 2014).

The finding of this study did not support earlier literature on the influence of gender on behaviour. Previous studies (Goleman 1998; Guy \& Newman, 2004) found female participants showing additional assets to an organization that focus on interpersonal skills including caring, negotiating, or moderating conflict. In fact, Madonna and Gainor (2001) discovered that females show greater degree of emotional intelligence compared to their male counterpart.

\section{CONCLUSION}

This study has provided meaningful insight into the effectiveness of emotional intelligence and brainwriting creativity training programmes in enhancing peacebuilding skills of adolescents in Ogun East Senatorial District of Ogun State, Nigeria. It also showed the potency of the two techniques in enhancing adolescents' peacebuilding skills. 
However, brainwriting creativity technique showed better outcome than emotional intelligence as indicated by the mean scores of the two techniques. Based on the outcome of the study, the following conclusions were drawn:

The participants' peacebuilding skills improved significantly as a result of the treatment; the two treatments used in this study, individually boosted adolescents' peacebuilding skills.

The study further revealed that personality had no significant effect on participants' peacebuilding skills. Also, treatment and personality had no significant effect on participants' peacebuilding skills and treatments and the two moderators (personality and gender) had no interaction effect on adolescents' peacebuilding skills.

Based on the findings of this study and ample research evidence (Coskun, 2005; Heslin, 2009; Kohn, Paulus, \& Choi, 2011; Tsai, 2015) pointing to the fact that human behaviour, outcomes and achievements are directly influenced by their levels of creative and emotional learning competencies, it is thus recommended that schools, workplace, governmental bodies, research, training and academic institutions make it a point of duty to include creativity and emotional intelligence training programmes in their training curricular. These skills are essentials to handling anger, managing conflicts, developing empathy, and controlling impulses and ultimately fostering peace among faculty, work groups/teams and community members.

\section{REFERENCES}

[1] Adekunle, A. R. 2012. Relative effectiveness of SIMPLEX and APCAW techniques in fostering business creativity and innovation competence of managers in Lagos state, Nigeria. An unpublished $\mathrm{PhD}$ Thesis. Olabisi Onabanjo University, Ago-Iwoye.

[2] Adeniga, Ayodele, Adeoye \& Oyerinde, 2015. Self-efficacy, emotional intelligence and achievement motivation as predictors of impulseive behaviour among seconadary school student. Babcock Univeristy Journal of Education, 1 (1), 35-40

[3] Adeyemo, D. A. \& Ogunyemmi, A. O. 2006. Emotional intelligence and self-efficacy as predictors of occupational stress among academic staff in a Nigerian University. Journal of Organizational Learning and Leadership, 4, 1-14.

[4] Akinboye, J. O. 2003. Creativity, innovation and success. Ibadan: Stirling Holden Publishers (Nig) Ltd.

[5] Alharbi M. A. \& Wan Khairuzzaman Wan Ismail 2012. The Impact of Personality Traits and Employee Work-Related Attitudes on Employee Performance with the Moderating Effect of Organizational Culture: The Case of Saudi Arabia. Asian Journal of Business and Management Sciences, 1 (10), 108-127.

[6] Ayodele, K. O. 2014. Comparative effectiveness of rational emotive behaviour therapy, enhanced thinking, and social skills training in fostering adolescents' inter and intra-personal relationship. An unpublished PhD Thesis. Olabisi Onabanjo University

[7] Azeez, R. O. 2012. Fostering Emotional Labour and Innovative Competence of Social Workers through Six Thinking Hats and Emotional Intelligence Training Programme. An unpublished PhD Thesis. Olabisi Onabanjo University, Ago-Iwoye.

[8] Azeez, R. O. 2015. Enhancing peacebuilding skills among secondary school students: An empirical assessment of emotional intelligence. Research in Humanities and Social Sciences, 5(18), 150-156

[9] Azeez, R. O. 2015. The mediating impact of emotional intelligence and brainwriting creativity skill training programmes in enhancing Peacebuilding skills among secondary school students. Babcock Univeristy Journal of Education, 1 (1), 1-9.

[10] Baer, J., \& Kaufman, J. C. 2005. Bridging Generality and Specificity: The Amusement Park Theoretical (APT) Model of Creativity. Roeper Review.

[11] Bar-On, R. 2006. The Bar-On model of Emotional-Social Intelligence (ESI). Psicothema, 18 , supl., 13-25

[12] Barrick, M.R., \& Mount, M.K. 1993. Autonomy as a moderator of the relationships between the Big Five personality dimensions and job performance. Journal of Applied Psychology. 78, 111118.

[13] Beer, A., \& Brooks, C. 2011. Information quality in personality judgment: The value of 
personal disclosure. Journal of Research in Personality, 45 (2), 175-185.

[14] Berenson, R., Boyles, G., \& Weaver, A. 2008; EmotionaI intelligence as a Predictor for Success in Online Learning. International Review of Research in Open and Distance Learning, 9 (2), 117

[15] Boutros-Ghali, B. 1992. Agenda for peace: Preventive diplomacy, peacemaking and peacekeeping (Report of the UN Secretary-General, $47^{\text {th }}$ General Assembly).

[16] Bunevicius, A., Katkute, A., \& Bunevicius, R. 2008. Symptoms of anxiety and depression in medical students and in humanities students: Relationship with big-five personality dimensions and vulnerability to stress. International Journal of Social Psychiatry, 54(6), $494-501$.

[17] Chan, D. W. 2005. Self-perceived creativity, family hardiness, and emotional intelligence of Chinese gifted students in Hong Kong. Journal of Secondary Gifted Education, 16, 47-56.

[18] Cherniss, C., Goleman, D., Emmerling, R. Cowan, K., Adler M. (1998). Bringing Emotional Intelligence to the workplace. New Brunswick, NJ: Consortium for research on Emotional Intelligence in organizations, Rutgers University.http://www.eiconsortium.org

[19] Ciarrochi, J., Deande, F.P. \& Anderson, S. 2001. Emotional intelligence moderates the relationship between stress and mental health. Personality and Individual Differences, 32 (2), 197-209.

[20] Connolly, J. J., \& Viswesvaran, C. 2000. The role of affectivity in job satisfaction: A metaanalysis. Personality and Individual Differences, 29, 265-281.

[21] Coskun, H. (2005). Cognitive stimulation with convergent and divergentthinking exercises in brainwriting: Incubation, sequence priming, and group context. Small Group Research, 36, 466-498.

[22] de Bono, E. 2000. The De Bono Code Book: Going Beyond the Limits of Language: Pengiun Books Ltd.

[23] de Bono, E. 2008. Applications for (dB) new think. http://www.debonogroup.com/applications.htm.

[24] DeNeve, K. M., \& Cooper, H. 1998. The happy personality: A meta-analysis of 137 personality traits and subjective well-being. Psychological Bulletin, 124, 197-229.

[25] Deniz, M. E., Tras, Z., \& Aydogan, D. 2009. An Investigation of Academic Procrastination, Locus of Control, and Emotional Intelligence. Educational Sciences: Theory \& Practice, 9 (2), 623-632

[26] Donohue, W. A. and Kolt, R. 1992. Managing Interpersonal Conflict. Newbury Park California: Sage Publications.

[27] Erdheim, J., Wang, M., Zickar, M.J. 2006. Linking the big five personality constructs to organizational commitment, Personality and Individual Differences, 41 (5), .959-70.

[28] Fajana, S. 2002. Human Resources Management. An Introduction. Labofin and Company.

[29] Fisher, S., Ludin, J., Williams, S., Abdi, D. I., Smith, R. \& Williams, S. 2000. Working with conflict: Skills and strategies for action. Zed Books Ltd, London.

[30] Goodman, G. 1995. Brainwriting: What to do when there's not a cloud in the brainstorming sky. In J. Heilbrunn (Eds.), Marketing encyclopedia: Issues and trends shaping the future (pp. 40-46). Lincolnwood, IL: NTC Business Books.

[31] Gosling, S. C., Rentfrow, P. J., \& Swann, W. B. Jr. 2003. A very brief measure of the Big-Five personality domains. Journal of Research in Personality, 37, 504-528.

[32] Grandey, A. A. 2000. Emotion regulation in the workplace: A new way to conceptualize emotional labor. Journal of Occupational Health Psychology, 5, 95-110

[33] Guy, M. E. \& Newman, M. A. 2004. Women's jobs, men's jobs: Sex segregation and. emotional labour. Public Administration Review, 64 (3) 289-298.

[34] Hanley, S. J., \& Abell, S. C. 2002. Maslow and relatedness: Creating an interpersonal model of self-actualization. Journal of Humanistic Psychology, 42(4), 37-57.

[35] Heslin, P. A. 2009. Better than brainstorming? Potential contextual boundary conditions to brainwriting for idea generation in organizations. Journal of Occupational and Organizational Psychology, 82, 129-145.

[36] Iro-Idoro, C. B. 2014. Assertiveness, emotional intelligence and interpersonal skills training programmes as strategies for enhancing nurses' work attitude in Ogun state. An unpublished 
$\mathrm{PhD}$ Thesis. Olabisi Onabanjo University, Ago-Iwoye.

[37] Joseph D. L., Jin, J., Newman, D. A. \& O'Boyle, E. H.2015. Why does self-reported emotional intelligence predict job performance? A meta-analytic investigation of mixed EI. Journal of Applied Psychology, 100 (2), 298-342.

[38] Joseph, D. L. Newman, D. A. 2010. Emotional Intelligence: An Integrative Meta-Analysis and Cascading Model. Journal of Applied Psychology, 95, (1), 54 -78.

[39] Joshanloo, M., \& Afshari, S. 2009. Big five personality traits and self-esteem as predictors of life satisfaction in Iranian Muslim university students. J Happiness Stud, 12, 105-113.

[40] Judge, T. A., Bono, J. E., Ilies, R., \& Gerhardt, M. W. 2002. Personality and leadership: A qualitative and quantitative review. Journal of Applied Psychology, 87, 765-780.

[41] Kohn, N. W., Paulus, P. B., \& Choi, Y. 2011. Building on the ideas of others: An examination of the idea combination process. Journal of Experimental Social Psychology, 47, 554-561.

[42] Law, K. S., Wong, C. S., \& Song, L. J. 2004. The construct and criterion validity of emotional intelligence and its potential utility for management studies. Journal of Applied Psychology, 89, $483-496$.

[43] Linsey, J. S. \& Becker, B. 2012. Effectiveness of brainwriting techniques: Comparing nominal groups to real teams pp 165-171. London: Springer

[44] Mabekoje, S. O. 2012. Development and validation of self-report and performance-based measures of emotional intelligence. Olabisi Onabanjo University, Ago-Iwoye. Unpublished Ph.D. Thesis

[45] Madonna, G. C. \& Gainor K. A. 2001. Emotional intelligence and empathy. Their relation to multicultural counselling knowledge and awareness. issue.

[46] Mayer, J. D., Roberts, R. D., \& Barsade, S. G. 2008. Human abilities: Emotional intelligence. Annual Review of Psychology, 59, 507-536.

[47] Mayer, J. D., \& Salovey, P. 1993. The intelligence of emotional intelligence. Intelligence, 17, 433- 442.

[48] McCrae, R. R., \& Costa, P. T., Jr. 1992. Revised NEO Personality Inventory (NEO-PI-R) and NEO Five-Factor Inventory (NEO-FFI). Odessa, FL: Psychological Assessment Resources.

[49] McElroy, T., \& Dowd, K. 2007. Susceptibility to anchoring effects: How openness-toexperience influences responses to anchoring cues. Judgment and Decision Making, 2(1), 48 53.

[50] McMaster, 2011. Male and Female Creativity: Is there a difference? Retrieved from $\mathrm{http} / /$ marcisegal.ipree.com/male and female creativity on $12^{\text {th }}$ September, 2011.

[51] Michinov, M. 2012. Is Electronic Brainstorming or Brainwriting the Best Way to Improve Creative Performance in Groups? An Overlooked Comparison of Two Idea-Generation Techniques. Journal of Applied Social Psychology, 42, 222-243.

[52] Mikolajczak, M. Luminet, O. 2008. Trait emotional intelligence and the cognitive appraisal of stressful events: An exploratory study. Personality and Individual Differences, 44, 1445-1453

[53] Mikolajczak, M., Menil, C. \& Luminet, O. 2007. Explaining the protective effect of trait emotional intelligence regarding occupational stress: exploration of emotional labour process. Journal of Research in Personality, 41, 1107-1117.

[54] Ogunyemi, A. O. 2010. Provocation and emotional mastery techniques as strategies for fostering creative thinking competence among Nigerian adolescents. Journal of Social Science , 22 (1), 25-32.

[55] Okunuga, O. O. 2014. Effects of brainstorming, negotiation skills and peer mediation training on conflict resolution skills of industrial workers in Ogun state, Nigeria. Olabisi Onabanjo University, Ago-Iwoye. Unpublished Ph.D. Thesis

[56] Onabamiro, A. A. \& Anatsui, T. C. 2015. Path-analytic study of the influence of neuroticism, extraversion, openness, agreeableness, social reaction on socio-reactivity of secondary school adolescents in Ogun and Oyo states, Nigeria. Babcock Univeristy Journal of Education, 1 (1), 29-34.

[57] Orija, J. 2015. Brainstorming and brainwriting training programmes as strategies for fostering creativity among civil servants in Ogun state. Olabisi Onabanjo University, Ago-Iwoye. Unpublished Ph.D. Thesis 
[58] Ortese, P. T. 2005. CORT-1 and mind-prompt determinants of creativity performance among secondary school students in Makurdi, Benue state, Nigeria. An unpublished Ph.D. Thesis submitted to the Guidance and Counselling Department, University of Ibadan.

[59] Ozer, D. J., \& Benet-Martinez, V. 2006. Personality and the Prediction of Consequential Outcomes. Annual Review of Psychology, 57, 401-421.

[60] Sackett, P.R., Gruys, M.L., \& Ellingson, J.E. 2002. Ability-personality interactions when predicting job performance. Journal of Applied Psychology, 83(4), 545-556.

[61] Sasser, S. L. 2006. Creativity, innovation \& integration in global advertising agency channel relationships creativity in the real world. Unpublished doctoral dissertation, Wayne State University, Detroit, Michigan.

[62] Schulman, S. 2011. The use of personality assessments to predict job performance. Burlington: The University of Vermont.

[63] Strobel, M., Tumasjan, A., \& Sporrle, M. 2011. Be yourself, believe in yourself, and be happy: Self-efficacy as a mediator between personality factors and subjective well-being. Scandinavian Journal of Psychology, 52, 43-48.

[64] VanGundy, A. B. 1999. Productivity Loss in Brainstorming and Brainwriting Groups, Norman, OK; University of Oklahoma, Unpublished paper.

[65] von Hippel, W., \& Gonsalkorale, K. 2005. That is bloody revolting: Inhibitory

[66] World Bank 2011. Conflict, Security, and Development.New York:The International Bank for Reconstruction and Development/the World Bank

[67] Zelenski, J.M., Santoro, M.S., \& Whelan, D.C. 2012. Would introverts be better off if they acted more like extraverts: Exploring the emotional and cognitive consequences of counterdispositional behaviour? Emotion, 12, 290-303.

[68] Tsai, K. C. 2015. Thking styles, creative preference, and creative personality among Chinese students in Macau. International Journal of Psychological Studies, 7 (1), 67-74 